\title{
POLA BAKTERI PENYEBAB INFEKSI NOSOKOMIAL PADA RUANG PERAWATAN INTENSIF ANAK DI BLU RSUP PROF. DR. R. D. KANDOU MANADO
}

\author{
${ }^{1}$ Anastashia Baharutan \\ ${ }^{2}$ Fredine E. S. Rares \\ ${ }^{2}$ Standy Soeliongan \\ ${ }^{1}$ Kandidat Skripsi Fakultas Kedokteran Universitas Sam Ratulangi Manado \\ ${ }^{2}$ Bagian Mikrobiologi Kedokteran Universitas Sam Ratulangi Manado \\ Email: tasya_baharutan@yahoo.com
}

\begin{abstract}
Nosocomial infections is an infection acquired in the hospital in patients treated for at least 72 hours (3x24 hours). Environmental infection caused by bacteria from an existing object within the hospital. Microorganisms are often potentially causing nosocomial infections are Proteus sp., Escherichia colii, Staphylococcus aureus, Candida albicans, and Pseudomonas aeruginosa. Objective: to know the most aerobic bacteria and the pattern of aerobic bacteria in Pediatric Intensive Care Unit at BLU Dr Prof. Dr R. D. Kandou. Methods: 24 swab samples were taken on the surface of the tool, treatment rooms and 6 samples of air space. Identification of bacterial cultures taken on an agar medium, gram staining and biochemical tests. Results: identified bacteria obtained 11 types of microorganisms, such as Bacillus subtilis, Staphylococcus sp., Enterobacter agglomerans, Serratia rubidaea, Enterobacter aerogenes, Enterobacter cloacae, Coccus Gram-negative, Klebsiella pneumoniae, Candida sp., Pseudomonas sp., Streptococcus sp. Conclusion: Gram negative bacteria are bacteria that are found in the Pediatric Intensive Care Unit. Staphylococcus sp., and Pseudomonas sp., a common bacteria that cause nosocomial infections with Staphylococcus sp., a bacterium that is most found.

Keywords: bacteria, germs pattern, nosocomial infections, pediatric intensive care unit.
\end{abstract}

\begin{abstract}
Abstrak: Infeksi nosokomial merupakan infeksi yang didapat di rumah sakit pada pasien yang dirawat paling tidak selama 72 jam (3x24 jam). Infeksi lingkungan yang disebabkan oleh bakteri dari benda yang ada dilingkungan rumah sakit. Mikroorganisme yang sering berpotensi menyebabkan infeksi nosokomial adalah Proteus sp., Escherichia colii, Staphylococcus aureus, Candida albicans, dan Pseudomonas aeruginosa. Tujuan: mengetahui bakteri aerob terbanyak dan pola dari bakteri aerob tersebut pada Ruang Perawatan Intensif anak di BLU RSUP Prof. Dr. R. D. Kandou. Metode: sampel diambil pada 24 usapan permukaan alat, ruangan perawatan dan 6 sampel udara ruang. Identifikasi bakteri dilakukan kultur pada media agar, pewarnaan gram dan uji biokimia. Hasil: bakteri yang teridentifikasi didapatkan 11 jenis mikroorganisme, yaitu Bacillus subtilis, Staphylococcus sp., Enterobacter agglomerans, Serratia rubidaea, Enterobacter aerogenes, Enterobacter cloacae, Coccus Gram negatif, Klebsiella pneumoniae, Candida sp., Pseudomonas sp., Streptococcus sp. Kesimpulan: bakteri gram negatif merupakan bakteri yang banyak ditemukan pada Ruang Perawatan Intensif anak. Staphylococcus sp., dan Pseudomonas sp., merupakan bakteri tersering yang menyebabkan infeksi nosokomial dengan Staphylococcus sp., merupakan bakteri yang terbanyak ditemukan. Kata kunci: bakteri, pola kuman, infeksi nosokomial, ruang perawatan intensif anak.
\end{abstract}


Infeksi nosokomial atau yang sekarang disebut sebagai Health care Associated Infection (HAIs) adalah infeksi yang didapat di rumah sakit terjadi pada pasien yang dirawat di rumah sakit paling tidak selama 72 jam dan pasien tersebut tidak menunjukkan gejala infeksi saat masuk rumah sakit. ${ }^{1,2}$ Infeksi lingkungan disebabkan oleh bakteri dari benda atau bahan yang tidak bersenyawa yang berada di lingkungan rumah sakit. Misalnya lingkungan yang lembab. Jenis mikroorganisme yang sering berpotensi terjadinya infeksi nosokomial yaitu: Proteus sp., Escherichia colii, Staphylococcus aureus, Candida albicans, dan Pseudomonas aeruginosa.,

Penelitian yang dilakukan oleh WHO menunjukkan bahwa sekitar 8,7\% dari 55 rumah sakit dari 14 negara yang berasal dari Eropa, Timur Tengah, Asia Tenggara dan Pasifik menunjukkan adanya infeksi nosokomial dan untuk Asia Tenggara sebanyak 10,0\%. Data dari Centers for Disease Control and Prevention (CDC), National Nosocomial Infection Surveillance (NNIS) antara tahun 1992-1997 infeksi ini menempati posisi keempat penyebab kematian di Amerika Serikat dan terdapat 20.000 kematian tiap tahunnya akibat infeksi nosokomial ini. Dari 40 juta penderita yang dirawat di rumah sakit pertahun, didapatkan angka Infeksi Nosokomial antara 5-10\% (18\% diantaranya dengan lebih dari 1 macam Infeksi Nosokomial) dengan angka kematian 1\%, 5-10 hari kelebihan hari rawat setiap penderita, kerugian antara 2-6 milyar dolar Amerika pertahun. Infeksi didapat dari rumah sakit di ICU pada 7,8\% dari seluruh pasien yang dirawat (14.177 diantara 181.993 pasien). Infeksi saluran kemih (31\%) merupakan infeksi tersering, 95\% kasus diantaranya mendapat kateterisasi, $86 \%$ kasus pneumonia berhubungan dengan ventilator associated pneumonia (VAP). Penyakit ini merupakan $27 \%$ dari seluruh infeksi nosokomial, sedangkan bloodstream infection (BSI) mewakili $19 \% \quad(18,2 \%$ terbukti secara laboratoris dan $0,8 \%$ sepsis secara klinis). Di Indonesia, infeksi nosokomial mencapai $15,74 \%$ jauh di atas negara maju yang berkisar 4,8-15,5\%. Di rumah sakit Yogyakarta insidensi terjadi infeksi nosokomial secara umum sebesar 5,9\%. Di rumah sakit DKI Jakarta tahun 2004 menunjukkan bahwa 9,8 \% pasien rawat inap mendapat infeksi yang baru selama dirawat. ${ }^{5,6}$

Berdasarkan informasi sekunder yang ada, dapat disimpulkan infeksi nosokomial menjadi masalah yang sering ditemukan di rumah sakit karena pengaruh lingkungan sekitar yang terkontaminasi. Maka perlu dilakukan penelitian mengenai hal ini.

Tujuan penelitian ini untuk mengetahui pola bakteri yang menyebabkan infeksi nosokomial dan mengetahui bakteri aerob terbanyak penyebab infeksi nosokomial di ruang perawatan intensif anak

\section{METODE PENELITIAN}

Penelitian ini bersifat deskriptif yang dilakukan pada bulan November 2014 sampai dengan Januari 2015. Sampel penelitian diambil masing-masing pada permukaan peralatan medis, permukaan meja, permukaan tempat tidur, permukaan lantai, permukaan dinding dengan cara swab dengan lidi kapas steril yang telah dicelupkan $\mathrm{NaCl}$ Fisiologis. Sedangkan pengambilan sampel udara dilakukan secara pasif menggunakan media agar Nutrien dan media agar Mac Conkey.

\section{HASIL PENELITIAN}

Pengambilan sampel sebanyak 24 sampel dari usapan permukaan lantai, dinding, alat dan 6 sampel udara (Tabel 1).

Distribusi sampel berdasarkan hasil kultur dari 30 sampel yang diteliti, bakteri yang tumbuh pada Agar Nutrien sebanyak 25 sampel (83,33\%), sedangkan pada Mac Conkey agar sebanyak 20 sampel (66,67\%) (Tabel 2).

Pada Tabel 3 terdapat 9 sampel bakteri gram positif dan 9 sampel bakteri gram 
negatif dengan persentasi masing-masing $34,62 \%$ sedangkan bakteri gram positif dan negatif ada 8 sampel dengan persentasi $30,77 \%$.

Tabel 4 menunjukkan distribusi 30 sampel yang diteliti, Bacillus subtilis merupakan bakteri terbanyak dengan 8 sampel (26,67\%); Staphylococcus sp. dengan 5 sampel (16,67\%); Enterobacter agglomerans 4 sampel (13,33\%); Serratia rubidaeas 3 sampel (10,00\%); Enterobacter aerogenes, Enterobacter cloacae, Coccus Gram negatif didapatkan 2 sampel masing-masing (6,67\%); dan Klebsiella pneumoniae, Candida sp., Pseudomonas sp., Streptococcus sp. masing-masing 1 sampel (3,33\%).

Tabel 1. Distribusi Pengambilan Sampel

\begin{tabular}{llcc}
\hline Kategori & Sampel & $\begin{array}{c}\text { Jumlah } \\
\text { Sampel }\end{array}$ & \% \\
\hline Ruang & Perawatan & 5 & 16,67 \\
& $\begin{array}{l}\text { Lantai } \\
\text { Dinding }\end{array}$ & 4 & 13,33 \\
Umum & Meja & 3 & 10,00 \\
& Tempat & & \\
& Tidur & 5 & 16,67 \\
& Tabung & & \\
Peralatan & dan & 3 & 10,00 \\
Medis & Selang $\mathrm{O}_{2}$ & & \\
& Portable & & 3,33 \\
& Nirbeken & 1 & 3,33 \\
& Bak & 1 & 3,33 \\
& Suction & 1 & \\
& Weigth & & 3,33 \\
Udara & Milk & 1 & 10,00 \\
& Scale & & 10,00 \\
Total & Pagi & 3 & $\mathbf{1 0 0}$ \\
\hline
\end{tabular}

Tabel 2. Distribusi Pertumbuhan Bakteri

\begin{tabular}{ccc}
\hline Media & $\begin{array}{c}\text { Agar } \\
\text { Nutrien }\end{array}$ & $\begin{array}{c}\text { Agar Mac } \\
\text { Conkey }\end{array}$ \\
\hline $\begin{array}{c}\text { Ada } \\
\text { Pertumbuhan } \\
\text { Tidak Ada } \\
\text { Pertumbuhan }\end{array}$ & 25 & 20 \\
\hline Total & 5 & 10 \\
\hline
\end{tabular}

Tabel 3. Hasil Pewarnaan

\begin{tabular}{lcc}
\hline \multicolumn{1}{c}{ Bakteri } & $\begin{array}{c}\text { Jumlah } \\
\text { Sampel }\end{array}$ & $\begin{array}{c}\text { Persentasi } \\
\text { (\%) }\end{array}$ \\
\hline Gram Positif & 9 & 34,62 \\
Gram Negatif & 9 & 34,62 \\
Gram Positif dan & & \\
Negatif & 8 & 30,77 \\
Total & 26 & 100 \\
\hline
\end{tabular}

Tabel 4. Hasil Identifikasi Bakteri dari Ruang Perawatan Intensif Anak

\begin{tabular}{|c|c|c|}
\hline Bakteri & Jumlah & $\begin{array}{c}\text { Persentasi } \\
(\%)\end{array}$ \\
\hline Basillus Suptilis & 8 & 26,67 \\
\hline Staphylococcus sp & 5 & 16,67 \\
\hline $\begin{array}{l}\text { Enterobacter } \\
\text { agglomerans }\end{array}$ & 4 & 13,33 \\
\hline Serratia rubidaea & 3 & 10,00 \\
\hline $\begin{array}{l}\text { Enterobacter } \\
\text { aerogenes }\end{array}$ & 2 & 6,67 \\
\hline $\begin{array}{l}\text { Enterobacter } \\
\text { cloacae }\end{array}$ & 2 & 6,67 \\
\hline $\begin{array}{l}\text { Coccus Gram } \\
\text { Negatif }\end{array}$ & 2 & 6,67 \\
\hline $\begin{array}{l}\text { Klebsiella } \\
\text { pneumonia }\end{array}$ & 1 & 3,33 \\
\hline Candida sp & 1 & 3,33 \\
\hline Pseudomonas sp & 1 & 3,33 \\
\hline Streptococcus sp & 1 & 3,33 \\
\hline Total & 30 & 100 \\
\hline
\end{tabular}

Tabel 5 menunjukkan Enterobacter agglomerans dan Serratia rubidaea memiliki distribusi terbanyak (33,33\%), sedangkan Enterobacter aerogenes, Coccus Gram negatif dan Streptococcus sp. memiliki distribusi sedikit dengan nilai yang sama (11,11\%).

Tabel 6 menunjukkan Bacillus subtilis memiliki distribusi terbanyak dari keseluruhan sampel pada perabotan ruang (50\%). Sedangkan Candida sp., Enterobacter agglomerans, Enterobacter aerogenes, Enterobacter cloacae, memiliki distribusi sedikit dengan nilai yang sama (12,5\%).

Tabel 7 menunjukkan Pseudomonas sp., Bacillus subtilis, Enterobacter cloacae, 
Klebsiella pneumoniae memiliki distribusi dengan nilai yang sama dari keseluruhan sampel peralatan medis (25\%).

Tabel 5. Hasil Identifikasi Bakteri Kategori Ruang Perawatan

\begin{tabular}{lcc}
\hline \multicolumn{1}{c}{ Bakteri } & Jumlah & $\begin{array}{c}\text { Persentasi } \\
(\mathbf{\% )}\end{array}$ \\
\hline $\begin{array}{l}\text { Enterobacter } \\
\text { agglomerans }\end{array}$ & 3 & 33,33 \\
$\begin{array}{l}\text { Serratia rubidaea } \\
\begin{array}{l}\text { Enterobacter } \\
\text { aerogenes }\end{array}\end{array}$ & 3 & 33,33 \\
$\begin{array}{l}\text { Coccus } \\
\text { negatif Gram }\end{array}$ & 1 & 11,11 \\
$\begin{array}{l}\text { Streptococcus sp. } \\
\text { Total }\end{array}$ & 1 & 11,11 \\
\hline
\end{tabular}

Tabel 6. Hasil Identifikasi Bakteri Katerogi Perabotan Ruang

\begin{tabular}{lcc}
\hline \multicolumn{1}{c}{ Bakteri } & Jumlah & $\begin{array}{c}\text { Persentasi } \\
(\mathbf{\% )}\end{array}$ \\
\hline $\begin{array}{l}\text { Bacillus subtilis } \\
\text { Candida sp. }\end{array}$ & 4 & 50 \\
$\begin{array}{l}\text { Enterobacter } \\
\text { agglomerans }\end{array}$ & 1 & 12,5 \\
$\begin{array}{l}\text { Enterobacter } \\
\text { aerogenes }\end{array}$ & 1 & 12,5 \\
$\begin{array}{l}\text { Enterobacter } \\
\text { loacae }\end{array}$ & 1 & 12,5 \\
Total & 1 & 12,5 \\
\hline
\end{tabular}

Tabel 7. Hasil Identifikasi Bakteri Kategori Peralatan Medis

\begin{tabular}{lcc}
\hline \multicolumn{1}{c}{ Bakteri } & Jumlah & $\begin{array}{c}\text { Persentasi } \\
(\%)\end{array}$ \\
\hline $\begin{array}{l}\text { Pseudomonas sp. } \\
\text { Bacillus subtillis }\end{array}$ & 1 & 25 \\
$\begin{array}{l}\text { Enterobacter } \\
\text { cloacae }\end{array}$ & 1 & 25 \\
$\begin{array}{l}\text { Klebsiella } \\
\text { pneumoniae }\end{array}$ & 1 & 25 \\
Total & 1 & 25 \\
\hline
\end{tabular}

Tabel 8 menunjukkan Staphylococcus sp. memiliki distribusi terbanyak dari keseluruhan sampel udara ruang (80\%), sedangkan Coccus Gram negatif memiliki distribusi sedikit dari keseluruhan sampel (20\%).

Tabel 8. Hasil Identifikasi Bakteri Kategori Udara Ruang

\begin{tabular}{lcc}
\hline \multicolumn{1}{c}{ Bakteri } & Jumlah & $\begin{array}{c}\text { Persentasi } \\
(\%)\end{array}$ \\
\hline $\begin{array}{l}\text { Staphylococcus } \\
\text { sp. }\end{array}$ & 4 & 80 \\
$\begin{array}{l}\text { Coccus } \quad \text { Gram } \\
\text { negative }\end{array}$ & & \\
Total & 1 & 20 \\
\hline
\end{tabular}

\section{BAHASAN}

Pengambilan sampel dilakukan pada ruang perawatan intensif anak (RPI Anak) di bagian perawatan. Ruangan tersebut tidak mendapatkan sinar matahari langsung pada pagi hari dan sore hari. Siklus udara yang ada dalam ruangan diatur dari Air Conditioner (AC) dan pencahayaan dari lampu listrik. Dalam ruangan tersebut terdapat perabotan umum ruangan dan peralatan medis. Aktifitas yang sering terjadi dalam ruangan hanya terlihat dari tenaga medis, pasien dan keluarga pasien.

Bacillus Subtilis merupakan flora normal di tanah, udara, air dan kompos tanah. Sedangkan pada penelitian ini, bakteri ditemukan di permukaan lantai, dinding, meja, tempat tidur dan nirbeken. Hal ini disebabkan karena bakteri ini dapat beradaptasi pada perubahan suhu lingkungan ekstrim dengan membentuk endospora. Bakteri ini bersifat mesofilik tidak patogenik, tapi bisa mencemari makanan namun jarang menyebabkan keracunan makanan. ${ }^{7,8}$

Pada sampel yang diteliti, bakteri ini ikut bersama air pada saat lantai dibersihkan dengan kain pel, dinding dan meja yang dilap dengan kain basah dan nirbeken yang dicuci menggunakan air saja.

Staphylococcus sp. merupakan flora normal pada kulit dan selaput lendir manusia. Pada penelitian ini, ditemukan di 
udara pada pagi hari dan Weigth Milk Scale karena ditransportasikan melalui droplet pengunjung, keluarga pasien atau pasien sendiri. Perpindahan melalui tangan medis juga menjadi transport kuman berpindah pada Weigth Milk Scale. Bakteri ini bisa bersifat patogen karena sering menghemolisis darah, mengkoagulasi plasma dan menghasilkan beberapa enzim dan toksin yang stabil pada suhu panas. Hal ini mengakibatkan bakteri ini bisa berada pada siklus udara ruang perawatan intensif anak yang terjadi pertukaran udara melalui AC menjadi tempat hidup dari bakteri. Bakteri ini bisa menyebabkan keracunan makanan dan toxic shock syndrome. ${ }^{9,10}$

Di RPI anak yang diteliti, ditemukan Staphylococcus sp. sebanyak 16,67\%. Dibandingkan dengan penelitian yang dilakukan oleh El - Bayoumi et all di PICU Mansoura University Children's Hospital, bakteri ini ditemukan 12,2\%. ${ }^{11}$

Enterobacter agglomerans dapat ditemukan di air, tanah, limbah, biji-bijian, sayuran, bahan keruh dan bahan. Bakteri tersebut ditemukan pada permukaan lantai dan tempat tidur saatn diteliti. Bakteri ini bersifat motil dengan bentuk gram negatif. Bakteri ini tergolong oportunistik dan komersial pada manusia dan hewan. ${ }^{7}$

Di Ruang perawatan intensif anak, bakteri ini ditemukan sebanyak 13,33\%. Sedangkan penelitian yang dilakukan oleh Jalal Mardaneh di NICU Iran, bakteri ini ditemukan pada susu formula sebanyak $6,4 \%{ }^{8}$

Serratia rubidaea bersifat chemoorganotrophic, termasuk bakteri anaerob fakultatif gram negatif dengan kebutuhan gizi rendah, pada famili Enterobacteriaceae. biasa ditemukan dalam makanan, terutama di varian tepung, permukaan tanah, air, dan tanaman. Dilaporkan juga bakteri ini ditemukan di saluran wastafel pembuangan dapur susu. Pada penelitian ini, bakteri ditemukan di dinding. ${ }^{13,14}$ Bakteri ini ditemukan sebanyak $10 \%$ pada penelitian ini, sedangkan penelitian yang dilakukan oleh
Steven D. Mahlen di rumah sakit Prancis ditemukan sebanyak $0,2 \%{ }^{15}$

Enterobacter aerogenes merupakan bagian dari saluran pencernaan manusia. Hal ini juga berada di dalam tanah, air dan produk susu. Umumnya infeksi timbul dari flora pasien sendiri. Namun infeksi silang dapat terjadi melalui tangan petugas kesehatan, selama penyisipan alat-alat medis dan prosedur bedah. ${ }^{16}$ Pada sampel yang diteliti, bakteri ini ditemukan sebanyak 6,67\%. Sedangkan penelitian yang dilakukan oleh Nataša Boban et all di NICU bakteri ini ditemukan sebanyak $18,6 \%{ }^{17}$

Enterobacter cloacae berbentuk batang gram negatif dari golongan Enterobacteriaceae. Bakteri ini hidup dengan suhu lingkungan mesofilik pada suhu $37^{\circ} \mathrm{C}$. dapat ditemukan pada kulit manusia dan jaringan buah dan sayur. Bakteri ini bukan patogen utama pada manusia, tapi berperan penting pada infeksi nosokomial. Infeksi yang sering ditimbulkan oleh bakteri ini antara lain bakteremia, infeksi kulit dan jaringan lunak, infeksi sistem pernapasan bagian bawah, infeksi saluran kemih, infeksi intraabdominal, osteomyelitis, infeksi mata, endokarditis dan septik arthritis. 13,16 Enterobacter cloaceae ditemukan sebanyak 6,67\% dari 30 sampel yang diteliti di RPI anak. Dibandingkan dengan penelitian yang dilakukan oleh Adriana Cristina de Oliveira et all di ICU Brazilian University Hospital, bakteri ini ditemukan 8,2\%. ${ }^{19}$

Klebsiella pneumoniae bakteri gram negatif non motil, tidak berkapsul. Bakteri ini melakukan fermentasi laktosa, bersifat anaerob fakultatif yang merupakan flora normal mulut, kulit, dan usus. Morfologi khas dari bakteri ini dapat dievaluasi dalam pertumbuhan padat in vitro dengan morfologi yang bervariasi dalam bahan klinik. Klebsiella dapat hidup sebagai saprofit pada lingkungan hidup, pada air, tanah, makanan, dan sayur-sayuran. Bakteri ini dapat menimbulkan infeksi pada saluran urin, paru-paru, saluran pernapasan, luka- 
luka, dan septiksemia. ${ }^{16}$ Bakteri ini ditemukan sebanyak 3,33\%. Dibandingkan dengan penelitian yang dilakukan oleh El Bayoumi et all di PICU Mansoura University Children's Hospital, Klebsiella pneumonia ditemukan sebanyak $19,1 \%{ }^{12}$

Pseudomonas sp merupakan bakteri yang berasal dari lingkungan. Bakteri ini biasanya hidup di tanah dan air. Pada tabung dan selang $\mathrm{O}_{2}$ ditemukan. Ini terjadi karena air dalam tabung $\mathrm{O}_{2}$ jarang diganti mengakibatkan perpindahan bakteri melalui selang $\mathrm{O}_{2} \cdot{ }^{13}$ Bakteri ini memiliki resistensi yang tinggi terhadap banyak obat antimikroba. ${ }^{20}$ Pada RPI anak, bakteri ini ditemukan sebanyak 3,33\%. Dibandingkan dengan penelitian yang dilakukan oleh $\mathrm{El}$ Bayoumi et all di PICU Mansoura University Children's Hospital, ditemukan sebanyak $11 \%$. Sedangkan penelitian yang dilakukan oleh Adriana Cristina de Oliveira et all di ICU Brazilian University Hospital ditemukan sebanyak 8,9\%. ${ }^{12,19}$

Streptococcus sp merupakan gram positif dengan bentuk bulat berderet membentuk rantai selama pertumbuhannya. Tidak motil dan tidak membentuk spora, kadang berkapsul. Tumbuh optimal pada suhu $37^{\circ} \mathrm{C}$ bersifat anaerob fakultatif. Spesies yang menyebabkan penyakit pada manusia yaitu, S. pyogenes, S. agalactiae, dan Enterococcus. ${ }^{4,20}$ Bakteri ini ditemukan pada permukaan dinding yang diteliti. Peneliti menemukan bakteri ini ditemukan sebanyak 3,33\% di RPI anak. Sedangkan penelitian yang dilakukan oleh Juhi Taneja et all di GB Pant Hospital bakteri ini ditemukan sebanyak $1.6 \%{ }^{21}$

Candida sp. juga ditemukan pada penelitian ini, namun tidak dibahas lebih lanjut mengenai jamur karena penelitian ini hanya mencakup bakteri aerob.

Penelitian yang dilakukan oleh Janas dkk di Rumah Sakit Khusus Penyakit Menular Jakarta pada perabotan ruangan, peralatan medis dan udara ditemukan bakteri batang bersprora aerob paling banyak (31,6\%), diikuti Coliform sp. (17,9\%), Staphylococcus epidermidis
(12,9\%), Pseudomonas aeruginosa (7,9\%), Clostrodium sp. (7,3\%), Klebsiella sp. (6,2\%), Streptococcus a haemolyticus (5,1\%), Clostridium welchii (4,5\%), Proteus sp. (2,8\%), E. colii (2,3\%), Staphylococcus aureus $(1,1 \%)$ dan Pseudomonas sp. (0,6\%). ${ }^{22}$

Sedangkan penelitian yang dilakukan di RPI anak BLU RSUP Prof. Dr. R. D. Kandou ditemukan jenis bakteri pada perabotan ruangan Bacillus subtilis memiliki distribusi terbanyak dari keseluruhan sampel pada perabotan ruang (50\%), sedangkan Candida sp., Enterobacter agglomerans, Enterobacter aerogenes, Enterobacter cloacae, memiliki distribusi sedikit dengan nilai yang sama $(12,5 \%)$.

Jenis bakteri yang ada pada peralatan medis Pseudomonas sp., Bacillus subtilis, Enterobacter cloacae, Klebsiella pneumoniae memiliki distribusi dengan nilai yang sama dari keseluruhan sampel peralatan medis (25\%). Dan bakteri yang ada pada udara ruang Staphylococcus sp. memiliki distribusi terbanyak dari keseluruhan sampel udara ruang (80\%), sedangkan Coccus Gram negatif memiliki distribusi sedikit dari keseluruhan sampel (20\%).

Pada penelitian infeksi nosokomial yang dilakukan oleh Michael J Richards et all di PICU United States, jenis bakteri yang ditemukan penyebab infeksi nosokomial yaitu Staphylococcus koagulasi negatif (38\%), Escherichia coli (19\%), dan Pseudomonas aeruginosa (22\%). ${ }^{23}$

Sedangkan penelitian yang dilakukan di RPI anak, jenis bakteri yang berpotensi menyebabkan infeksi nosokomial yaitu Bacillus subtilis merupakan bakteri terbanyak dengan 8 sampel (26,67\%); Staphylococcus sp. dengan 5 sampel (16,67\%); Enterobacter agglomerans 4 sampel (13,33\%); Serratia rubidaea 3 sampel (10,00\%); Enterobacter aerogenes, Enterobacter cloacae, Coccus Gram negatif didapatkan 2 sampel masingmasing (6,67\%); dan Klebsiella 
pneumoniae, Candida sp., Pseudomonas sp., Streptococcus sp. didapatkan 1 sampel masing-masing (3,33\%).

Masih kurangnya sterilitas ruangan, perabotan ruang, dan peralatan medis dapat dievaluasi dengan ditemukan banyaknya jumlah bakteri patogen berpotensi menyebabkan infeksi nosokomial yang teridentifikasi pada 30 sampel yang diteliti.

\section{SIMPULAN}

Berdasarkan hasil penelitian pola bakteri aerob penyebab infeksi nosokomial pada ruang perawatan intensif anak di BLU RSUP Prof. Dr. R. D. Kandou Manadodapat disimpulkan yaitu bakteri gram negatif merupakan bakteri yang banyak ditemukan pada Ruang Perawatan Intensif anak. Staphylococcus sp., dan Pseudomonas sp., merupakan bakteri tersering yang menyebabkan infeksi nosokomial dengan Staphylococcus sp., merupakan bakteri yang terbanyak ditemukan.

\section{SARAN}

Perlu penelitian kembali mengenai pertumbuhan bakteri penyebab infeksi nosokomial pada saat musim hujan dan panas, serta pengambilan sampel yang lebih banyak pada lokasi penelitian untuk mengetahui variasi bakteri penyebab infeksi nosokomial, serta dilakukan uji kepekaan pada bakteri penyebab infeksi nosokomial pada RPI anak.

\section{DAFTAR PUSTAKA}

1. Jeyamohan D, KTIS Angka Prevalensi Infeksi Nosokomial pada Pasien Luka Operasi Pasca Bedah dibagian Bedah RSU Pusat Haji Adam Malik, 2010

2. Irianto Koes. Mikrobiologi Medis. Bandung : Alfabeta. 2013 hal 328

3. Sudoyo AW, Setiyohadi B, Alwi I, Setiadi S. Ilmu Penyakit Dalam. Edisi V. Jakarta. 2009. Hal 2907-2908

4. Elliott T, Worthington T, Osman H, Gill M. Mikrobiologi Kedokteran \& Infeksi. Ed. 4. Jakarta : EGC. 2013. Hal 268
5. Bearman G. Nosocomial Infection. [cited 2014 sep 21]. Available from http://www.people.vcu.edu/ gbearma n/Adobe\%20files/BearmanNosokomi al_Infection[1].pdf

6. Eggimann P, Pittet D. Infection control in the ICU: critical care reviews. Chest 2001;120(6):2059-93

7. Rahmaningsih S, Wlis S, Mulyana A. Ekologia, Vol. 12 No.1 , April 2012 : 1-5.

8. Mardaneh, Jalal, Dallal, Soltan M. M. Isolation, identification and antimicrobial susceptibility of Pantoea (Enterobacter) agglomerans isolated from consumed powdered infant formula milk (PIF) in NICU ward: First report from Iran. Iranian journal of microbiology, 2013, 5.3: 263. [Citied 2015 Jan 22]. Available from

http://ijm.tums.ac.ir/index.php/ijm/art icle/viewFile/745/343

9. Hatmanti, A. Pengenalan Bacillus spp. 2000 [citied 2015 Jan 22]. Available from www.oseanografi.lipi.go.id

10.Public Health Agency of Canada. Pathogen Safety Data Sheet - Infectious Substances. 2012 [citied 2015 Jan 22]. Available from http://www.phacaspc.gc.ca/lab-bio/res/psdsftss/staphylococcus-aureus-eng.php

11.Medicinenet. Definition of Staphylococcus. 2012 [citied 2015 Jan 22]. Available from

http://www.medicinenet.com/script/m ain/art.asp?articlekey=5549\

12.El-Bayoumi MA, El-Nady GM, Badr RI. Clinical and Microbiological study of Nosocomial Infections in the Paediatric Intensive Care Unit (PICU) in Mansoura University Children's Hospital. 2006 [citied 2015 Jan 22]. Available from www.ejmm.eg.net/pdf/vol-15-no32006/4.pdf

13.Pratami, H. A., Apriliana, E., \& Rukmono, P. (2013). Identifikasi Mikroorganisme Pada Tangan Tenaga Medis dan Paramedis di Unit Perinatologi Rumah Sakit Abdul Moeloek Bandar Lampung. Majority, 2(5). 2013 [citied 2015 Jan 22]. 
Available from http://juke.kedokteran.unila.ac.id/inde x.php/majority/article/download/44/4 3

14.Public Health Agency of Canada. Serratia Spp.. 2012. [Citied 2015 Jan 22]. Available from http://www.phacaspc.gc.ca/lab-bio/res/psdsftss/serratia-spp-eng.php

15. Mahlen, Steven D. Serratia infections: from military experiments to current practice. Clinical Microbiology Reviews, 2011, 24.4: 755-791. [Citied 2015 Jan 22]. Available from http://www.tcd.ie/academicunits/scho ols/medicine/clinical_microbiology/a ssets/docs/mschim/serratia.pdf

16.Bioquell. Enterobacter aerogenes. [citied 2015 Jan 22]. Available from http://www.bioquell.com/enuk/resources-andsupport/microbiology/enterobacteraerogenes/

17.Boban N, Jerončić A, Punda-Polić V. Outbreak of nosocomial bacteremias, caused by Enterobacter gergoviae and Enterobacter aerogenes, in the neonatal intensive care unit, casecontrol study. 2011. [citied 2015 Jan 22]. Available from http://www.signavitae.com/attachmen ts/SIGNA\%20VITAE\%202011\%206 (1)\%2027\%20-\%2032.pdf

18.Danan, K. Klebsiellla pneumoniae 2008 Mei [citied 2015 Jan 22]. Available from

http://microbia.files.wordpress.com/2 008/05/cornelius-danan-r- 078114100.pdf

19.de Oliveira A. C, Kovner C. T, da Silva R. S. Nosocomial Infection in an Intensive Care Unit in a Brazilian University Hospital. 2010 [citied 2015 Jan 22]. Available from http://www.scielo.br/scielo.php?script $=$ sci_arttext $\&$ pid $=$ S010411692010000200014

20.Brooks F. Geo, Butel S. Janet, Morse A. Stephen. Mikrobiologi Kedokteran. Edisi 23. Jakarta : EGC. 2008. Hal 267

21.Taneja, Juhi, et al. Nosocomial bloodstream infections from extendedspectrum-beta-lactamase-producing Escherichia coli and Klebsiella pneumonia from GB Pant Hospital, New Delhi. The Journal of Infection in Developing Countries, 2010, 4.08: 517-520. [Citied 2015 Jan 22]. Available from http://www.jidc.org/index.php/journal /article/viewFile/668/427

22.Janas, Sutanto, Punjabi N. H. Pencemaran Kuman di Lingkungan Rumah Sakit Khusus Penyakit Menular Jakarta. 1992. [Citied 2015 Jan 22]. Available from

http://download.portalgaruda.org/artic le.php?article $=71287 \& \mathrm{val}=4882$

23.Richards, Michael J., et al. Nosocomial infections in pediatric intensive care units in the United States. Pediatrics, 1999, 103.4: e39-e39. [Citied 2015 Jan 22]. Available from http://pediatrics.aappublications.org/c ontent/103/4/e39.long 